\title{
Analisis Pemahaman Konsep Siswa pada Materi Relasi dan Fungsi Berdasarkan Teori APOS ditinjau dari Kemampuan Matematika Siswa Kelas VIII
}

\author{
Gustina $^{1, \text { a) }}$, Djadir $^{1, b)}$, dan Rusli ${ }^{2, c)}$ \\ ${ }^{1}$ Jurusan Matematika FMIPA Universitas Negeri Makassar \\ a) gustina18.unm@gmail.com \\ b)djadir@unm.ac.id \\ c) rusli@unm.ac.id
}

\begin{abstract}
Abstrak. Penelitian ini bertujuan untuk menganalisis pemahaman konsep siswa pada materi relasi dan fungsi berdasarkan teori APOS ditinjau dari kemampuan matematika. Subjek pada penelitian ini adalah tiga siswa. Instrumen yang digunakan adalah tes kemampuan matematika, tes pemahaman konsep pada materi relasi dan fungsi berdasarkan teori APOS, dan wawancara. Hasil penelitian menunjukkan bahwa: (1) Siswa dengan kemampuan matematika tinggi memahami konsep materi relasi dan fungsi dengan melakukan operasi secara aljabar (aksi), mensketsa grafik; melihat fungsi sebagai mesin input-output; dan menjelaskan definisi fungsi (proses), menjelaskan hubungan antara relasi dan fungsi; memahami syarat-syarat fungsi (objek), dan mengaplikasikan konsep (skema). (2) Siswa dengan kemampuan matematika sedang memahami konsep materi relasi dan fungsi dengan melakukan operasi secara aljabar (aksi), mensketsa grafik; melihat fungsi sebagai mesin input-output; dan menjelaskan definisi fungsi(proses), memahami syarat-syarat fungsi (objek). (3) Siswa dengan kemampuan matematika rendah memahami konsep materi relasi dan fungsi dengan melakukan operasi secara aljabar (aksi), mensketsa grafik; dan melihat fungsi sebagai mesin input-output (proses).
\end{abstract}

Kata Kunci: Kemampuan Matematika, Pemahaman Konsep, Teori APOS, Relasi, Fungsi

\begin{abstract}
This research aims to analyze students' conceptual understanding of relation and function material based on APOS theory in terms of mathematical ability. The subject of research are three students. The instruments used were tests of mathematics ability, tests of conceptual understanding in the relation and function material based on APOS theory, and interview. The result of the research showed that: (1) Students with high mathematical ability understand the concept of relation and function material by performing operations algebraically (action), sketching graphs; observed function as an input-output machine; and explain the definition of function (process), explained the relationships between relation and function; understand the unique properties of function (object), and apply concepts (schema). (2) Students with average mathematical ability understand the concepts of relation and function material by performing operations algebraically (action), sketching graphs; observed function as an input-output machine; and explained the function definition (process), and understand the unique properties of function (object). (3) Students with low mathematical ability understand the concept of relation and function material by performing operations algebraically (action), sketching graphs, and observed function as an input-output machine (process).
\end{abstract}

Keywords: Mathematical Ability, Understanding the Concept, APOS Theory, Relation, Function.

\section{PENDAHULUAN}

Pemahaman berasal dari kata "paham" yang berarti mengerti dengan benar dalam suatu hal. Sehingga, pemahaman konsep matematika adalah mengerti atau menguasai dengan baik suatu konsep. Dengan memahami suatu konsep matematika maka dapat menjelaskan keterkaitan antarkonsep dan mengaplikasikan konsep dalam pemecahan masalah (Depdiknas, 2006). 
Pemahaman konsep matematika menjadi sesuatu yang penting bagi siswa karena dengan pemahaman konsep yang baik maka akan berdampak pada pemecahan masalah yang baik pula. Sebagaimana Komariyah, dkk (2018) mengemukakan bahwa pemahaman konsep sangat penting dalam pembelajaran matematika, karena dengan pemahaman yang matang maka siswa dapat memecahkan suatu masalah.

Dubinsky mengemukakan suatu teori untuk mempelajari bagaimana seseorang belajar konsep matematika. Teori ini disebut teori APOS (Action, Process, Object, dan Shceme) (Asiala, dkk, 1997). Teori APOS dapat digunakan untuk mendeskripsikan konstruksi mental yang mungkin dilakukan oleh seorang anak dalam mengembangkan pemahamannya tentang suatu konsep. Struktur mental yang dimaksud yaitu melalui aksi, proses, objek dan skema (Asiala, dkk, 1997).

Teori APOS dapat gunakan untuk memahami pembelajaran dalam berbagai topik dalam kalkulus, aljabar abstrak, statistika, dan topik-topik matematika lainnya (Dubinsky \& McDonald, 2001). Teori APOS telah digunakan secara efektif untuk mendeteksi dan mengevaluasi tingkat pemahaman siswa dalam konsep fungsi (Chimhande, dkk, 2017).

Relasi dan fungsi adalah salah satu materi yang ada dalam pembelajaran matematika dikelas VIII. Salah satu kompetensi dasar yang harus dicapai oleh siswa adalah mendeskripsikan dan menyatakan relasi dan fungsi dengan menggunakan berbagai representasi (kata-kata, tabel, grafik, diagram dan persamaan). Materi relasi dan fungsi merupakan materi yang berlanjut hingga di perguruan tinggi. Oleh karena itu, pemahaman konsep pada materi relasi dan fungsi penting untuk dikuasai oleh siswa.

Setiap siswa memiliki kemampuan matematika yang berbeda-beda. Perbedaan kemampuan itu berdampak pada perbedaan siswa dalam memahami suatu konsep matematika (Febriana \& Budiarto, 2012). Dan mempengaruhi kemampuan seseorang untuk mengonstruksi pengetahuan dan pemahaman seseorang mengenai suatu materi (Safitri, dkk 2017). Kemampuan matematika terdiri dari tiga kategori yaitu kemampuan matematika tinggi, sedang dan rendah.

Beberapa penelitian yang telah dilakukan tentang pemahaman konsep berdasarkan teori APOS kaitannya dengan kemampuan matematika. Penelitian yang dilakukan oleh Rosali, dkk (2019) yang menunjukkan setiap kategori kemampuan matematika memiliki perbedaaan dalam memahami suatu konsep turunan berdasarkan teori APOS.

Penelitian lain dilakukan oleh Safitri, dkk (2017) menunjukkan bahwa hanya siswa dengan kemampuan matematika tinggi yang memenuhi semua tahapan teori APOS dalam memahami konsep fungsi kuadrat. Beberapa penelitian yang dilakukan sebelumnya mengkaji tentang turunan dan fungsi aljabar, sehingga penelitian ini memfokuskan menganalisis pemahaman konsep siswa pada materi relasi dan fungsi berdasarkan teori APOS ditinjau dari kemampuan matematika.

\section{KAJIAN PUSTAKA}

APOS adalah singkatan dari Action (Aksi), Process (Proses), Object (Objek) dan Schema (Skema). Teori APOS dapat digunakan untuk mendeskripsikan konstruksi mental yang mungkin dilakukan oleh seorang anak dalam mengembangkan pemahamannya tentang suatu konsep. Dalam memahami suatu konsep matematika dimulai dengan memanipulasi objek mental atau fisik yang dibangun sebelumnya untuk membentuk aksi, aksi kemudian diinternalisasi untuk membentuk proses yang kemudian dienkapsulasi untuk membentuk objek. Objek dapat didekapsulasi kembali ke proses. Akhirnya aksi, proses, dan objek dapat diatur dalam skema (Asiala, dkk, 1997). 


\section{Aksi}

Aksi adalah transformasi suatu objek yang dianggap indvidu sebagai sesuatu yang bersifat eksternal. Transformasi dilakukan dengan menanggapi isyarat ekternal yang memberikan rincian tepat tentang langkah apa yang harus diambil (Asiala, dkk, 1997).

\section{Proses}

Ketika suatu tindakan siulangi, dan individu merefleksikannya, tindakan itu dapat diinternalisasikan ke dalam suatu proses. Itu adalah kosntruksi internal yang dibuat dengan melakukan tindakan yang sama, tetapi sekarang tidak diarahkan oleh rangsangan ekternal (Asiala, dkk, 1997).

\section{Objek}

Weyer mengemukakan bahwa objek adalah suatu bentuk pemahaman terhadap suatu konsep matematika sebagai suatu penerapan dari aksi dan proses (Febriana \& Budiarto, 2012).

\section{Skema}

Skema untuk konsep matemtika tertentu adalah kumpulan tindakan, proses, objek dan skema lain dari individu yang dihubungkan oleh beberapa prinsip umum ke kerangka kerja dalam pikiran individu yang dapat dibawa ke situasi masalah yang melibatkan konsep tersebut (Dubinsky \& McDonald, 2001)

Beberapa penelitian yang mengkaji tentang pemahaman berdasarkan teori APOS. Penelitian yang dilakukan oleh Mulyono (2011) diperoleh bahwa teori APOS dapat digunakan sebagai alat analisis untuk mendeskripsikan perkembangan skema seseorang pada suatu konsep matematika yang merupakan totalitas dari pemahaman yang diperoleh melalui konstruksi mental dari aksi, proses, objek, dan skema. Dari sini dapat diketahui pemahaman individu yang berusaha membangun pemahamannya tentang konsep-konsep matematika.

Penelitian lain yang dilakukan oleh Syafri (2016) diperoleh bahwa teori APOS dapat digunakan untuk membandingkan kemampuan individu dalam mengkonstruksi mental yang telah terbentuk untuk suatu konsep matematika. Apabila terdapat dua individu yang kelihatannya sama-sama menguasai konsep matematika. Jika salah satu dari keduanya mampu menjelaskan lebih lanjut suatu konsep sedangkan yang satunya tidak mampu, maka secara otomatis ia berada pada tingkat pemahaman yang lebih baik dari pada yang satunya. Sehingga, disimpulkan bahwa teori APOS merupakan tahapan-tahapan individu dalam memahami konsep.

Selain itu, penelitian yang dilakukan oleh Maharaj (2010) diperoleh bahwa teori APOS mengusulkan bahwa seseorang harus memiliki struktur mental yang sesuai untuk memahami konsep matematika yang diberikan. Struktur mental merujuk pada kemungkinan aksi, proses, objek dan skema yang diperlukan untuk mempelajari konsep.

\section{METODE PENELITIAN}

Penelitian ini merupakan penelitian kualitatif yang menggunakan pendekatan deskriptif. Subjek pada penelitian ini adalah 3 orang siswa kelas VIII yang masing-masing mewakili setiap kategori yaitu kemampuan matematika tinggi (S1), sedang (S2), dan rendah (S3). Pemilihan subjek berdasarkan tujuan tertentu, yaitu nilai tes kemampuan matematika dan hasil diskusi dengan guru.

Instrumen yang digunakan adalah tes kemampuan matematika, tes pemahaman konsep pada materi relasi dan fungsi, dan pedoman wawancara. Ketiga instrumen yang digunakan telah melalui proses validasi oleh para validator ahli. Pengelompokan siswa berdasarkan kategori kemampuan matematika menurut Depdiknas (Widarti, 2013) disajikan pada Tabel 1. 
TABEL 1. Kategori kemampuan matematika

\begin{tabular}{cc}
\hline Nilai & Kategori \\
\hline $80 \leq$ nilai yang di peroleh $\leq 100$ & Kemampuan tinggi \\
$65 \leq$ nilai yang di peroleh $<80$ & Kemampuan sedang \\
$0 \leq$ nilai yang di peroleh $<65$ & Kemampuan rendah \\
\hline
\end{tabular}

Data yang terkumpul berupa jawaban hasil tes kemampuan matematika dan jawaban hasil tes pemahaman konsep pada materi relasi dan fungsi berdasarkan teori APOS, serta transkrip wawancara yang dianalisis menggunakan teknik analisis dengan langkah-langkah menurut Sugiyono (2017) yaitu reduksi data, penyajian data dan penarikan kesimpulan.

\section{HASIL DAN PEMBAHASAN}

Pemahaman konsep siswa pada materi relasi dan fungsi berdasarkan teori APOS diperoleh berdasarkan indikator-indikator pemahaman. Adapun indikator pemahaman konsep yang digunakan merupakan indikator yang dikembangkan dari karakteristik Mulyono (2011) dan Chimhande, dkk (2017) disajikan pada Tabel 2.

TABEL 2. Indikator Pemahaman Konsep Siswa pada Materi Relasi dan Fungsi Berdasarkan Teori APOS

\begin{tabular}{crl}
\hline Tahapan & & \multicolumn{1}{c}{ Indikator } \\
\hline Aksi & a. & Siswa menggunakan rumus yang diberikan untuk menentukan nilai \\
& suatu fungsi secara aljabar. \\
Proses & a. Siswa mensketsa grafik $f(x) ;$ \\
& b. Siswa menjelaskan hubungan $x$ dan $f(x)$ melalui prosedur memasangkan \\
& himpunan A dengan himpunan B (fungsi adalah mesin input-ouput); dan \\
Objek & c. Siswa menjelaskan definisi fungsi dengan bahasanya sendiri. \\
& a. Siswa menjelaskan hubungan antara relasi dan fungsi; \\
& b. Siswa menyebutkan dan menjelaskan syarat-syarat fungsi; dan \\
& c. Siswa mengidentifikasi dan mengklasifikasi suatu fungsi berupa grafik \\
& menurut syarat-syarat fungsi. \\
Skema & a. Siswa mengaplikasi konsep fungsi dalam pemecahan masalah yang \\
& berkaitan penentuan rumus fungsi; dan \\
& b. Siswa mudah dalam menentukan grafik dari persamaan dan persamaan \\
& dan grafik.
\end{tabular}

Setiap subjek penelitian yang mewakili masing-masing kategori kemampuan matematika diberikan tes pemahaman konsep dan dilakukan wawancara. Berdasarkan hasil jawaban dan wawancara subjek, diperoleh informasi mengenai pemahaman konsep siswa pada materi relasi dan fungsi yang disajikan pada Tabel 3 .

TABEL 3. Pemahaman Konsep Siswa pada Materi Relasi dan Fungsi Berdasarkan Teori APOS ditinjau dari Kemampuan Matematika

\begin{tabular}{|c|c|c|c|c|}
\hline \multirow{2}{*}{$\begin{array}{c}\text { Tahapan } \\
\text { Teori } \\
\text { APOS }\end{array}$} & \multirow[b]{2}{*}{ Indikator } & \multicolumn{3}{|c|}{ Kemampuan Matematika } \\
\hline & & Tinggi & Sedang & Rendah \\
\hline Aksi & $\begin{array}{l}\text { Siswa menggunakan rumus yang diberikan } \\
\text { untuk menentukan nilai suatu fungsi secara } \\
\text { aljabar. }\end{array}$ & $\sqrt{ }$ & $\sqrt{ }$ & $\sqrt{ }$ \\
\hline Proses & Siswa mensketsa grafik; & $\sqrt{ }$ & $\sqrt{ }$ & $\sqrt{ }$ \\
\hline
\end{tabular}




\begin{tabular}{lllll}
\hline & $\begin{array}{l}\text { Siswa menjelaskan hubungan } x \text { dan } f(x) \\
\text { (fungsi adalah mesin input-ouput); }\end{array}$ & $\sqrt{ }$ & $\sqrt{ }$ & $\sqrt{ }$ \\
$\begin{array}{l}\text { Siswa menjelaskan definisi fungsi dengan } \\
\text { bahasanya sendiri. } \\
\text { Siswa menjelaskan hubungan antara relasi } \\
\text { dan fungsi. }\end{array}$ & $\sqrt{ }$ & $\sqrt{ }$ & $\times$ \\
Objek & $\begin{array}{l}\text { Siswa menyebutkan dan menjelaskan } \\
\text { syarat-syarat fungsi. }\end{array}$ & $\sqrt{ }$ & $\sqrt{ }$ & $\times$ \\
$\begin{array}{l}\text { Siswa mengidentifikasi dan mengklasifikasi } \\
\text { suatu fungsi berupa grafik menurut syarat- } \\
\text { syarat fungsi }\end{array}$ & $\times$ & $\times$ & $\times$ \\
$\begin{array}{l}\text { Siswa mengaplikasi konsep fungsi dalam } \\
\text { pemecahan masalah yang berkaitan } \\
\text { penentuan rumus fungsi }\end{array}$ & $\sqrt{ }$ & $\times$ & $\times$ \\
$\begin{array}{l}\text { Siswa mudah menentukan grafik dari } \\
\text { persamaan dan persamaan dan grafik }\end{array}$ & $\times$ & $\times$ & $\times$ \\
\hline
\end{tabular}

\section{Subjek dengan Kemampuan Matematika Tinggi}

Pada tahap aksi, subjek mudah menentukan nilai suatu fungsi apabila diberikan suatu rumus fungsi yaitu dengan subjek mensubstitusikan nilai $x$ yang diketahui ke dalam $f(x)$. Subjek melakukan operasi aljabar untuk memperoleh nilai fungsi dari substitusi nilai yang dilakukan.

Asiala, dkk (1997) mengemukakan bahwa aksi adalah transformasi objek yang dianggap oleh individu sebagai sesuatu yang bersifat ekternal. Artinya, pemahaman individu hanya bereaksi terhadap isyarat eksternal yang memberikan rincian tentang langkah-langkah apa yang harus diambil dalam melakukan operasi. Subjek dapat melakukan operasi aljabar dan memberikan langkah-langkah operasi yang ia lakukan dalam menentukan nilai fungsi. Sehingga, disimpulkan bahwa subjek memenuhi indikator pada tahap aksi.

Pada tahap proses, subjek mensketsa grafik dari $f(x)$ dengan menentukan pasangan titik yang melibatkan proses menentukan nilai suatu fungsi. Selanjutnya, subjek melihat fungsi sebagai suatu input dan output yaitu dengan subjek menjelaskan bahwa apabila mensubstitusi sebuah nilai $(x)$ maka akan diperoleh suatu nilai keluaran $(f(x))$. Selain itu, subjek memberikan penjelasan tentang pengertian fungsi berdasarkan bahasanya sendiri.

Asiala, dkk (1997) mengemukakan bahwa ketika suatu tindakan diulangi, dan individu merenungkannya, itu mungkin diinternalisasi ke dalam suatu proses. Artinya, kontruksi mental dibuat dengan melakukan aksi yang sama. Subjek melakukan aksi yang berulang yaitu dalam menentukan pasangan titik untuk mensketsa grafik. Sehingga, disimpulkan bahwa subjek memenuhi indikator tahap proses.

\section{TRANSKRIP 1}

P1-01 : "Apakah semua fungsi adalah relasi?"

S1-01 : "Menurut saya iya kak, semua yang termasuk fungsi adalah relasi karena

sebagaimana relasi yang saya ketahui relasi hanyalah suatu hubungan antara himpunan A dengan himpunan B tanpa menggunakan syarat seperti fungsi yaitu bahwa setiap anggota himpunan A harus semuanya memiliki pasangan tepat satu tetapi relasi tidak.."

P1-02 : "Apakah semua relasi adalah fungsi?"

S1-02 : "Menurut saya kak, semua fungsi termasuk relasi. Tetapi jika semua relasi adalah fungsi itu tidak kak karena setiap relasi yang dikatakan fungsi harus memenuhi syarat-syarat fungsi"

P1-03 : "Kalau begitu, bagaimana syarat-syarat fungsi dek?" 
S1-03 : "Syarat-syarat fungsi. yaitu setiap anggota pada himpunan A memiliki pasangan kepada himpunan B dan tiap anggota pada himpunan A hanya memiliki tepat satu pasangan terhadap himpunan $B$ "

Pada Transkrip 1, subjek menjelaskan bahwa tidak semua relasi adalah fungsi karena relasi dikatakan fungsi harus memenuhi syarat-syarat fungsi (S1-02). Hal ini menunjukkan bahwa subjek dapat menjelaskan hubungan relasi dan fungsi yaitu dengan memahami bahwa fungsi adalah relasi yang bersyarat. Selain itu, subjek dapat menjelaskan syarat-syarat fungsi (S1-03).

Namun, subjek tidak mudah dalam mengidentifikasi suatu grafik termasuk fungsi atau bukan terutama pada grafik yang tidak berbentuk garis lurus. Subjek tidak menggunakan syarat-syarat fungsi dalam mengidentifikasi suatu grafik termasuk fungsi atau bukan. Sehingga, disimpulkan subjek tidak memenuhi satu indikator pada tahap objek.

Pada tahap skema, subjek mengaplikasikan konsep fungsi dalam pemecahan masalah yaitu dengan menggunakan persamaan bentuk umum fungsi dalam menyelesaikan soal. Namun, subjek tidak mudah dalam menentukan grafik dari persamaan yaitu subjek menjelaskan bahwa ia tidak dapat menggambar grafik dari suatu fungsi $f(x)$ yang tidak diketahui nilai-nilai $x$ nya.

Dubinsky \& McDonald (2001) mengemukakan bahwa skema adalah kumpulan tindakan, proses, objek dan skema lain dari individu yang dihubungkan oleh beberapa prinsip umum untuk membentuk kerangka kerja dalam pikiran individu yang dapat dibawa ke situasi masalah yang melibatkan konsep tersebut. Subjek melibatkan konsep fungsi yaitu dengan menggunakan bentuk umum fungsi dalam menyelesaikan soal. Sehingga, disimpulkan bahwa subjek memenuhi satu indikator pada tahap skema.

\section{Subjek dengan Kemampuan Matematika Sedang}

Pada tahap aksi, subjek dengan mudah melakukan operasi secara aljabar dalam menentukan nilai suatu fungsi apabila diberikan suatu rumus fungsi yaitu dengan mensubstitusikan nilai $x$ ke dalam $f(x)$. Sehingga, disimpulkan bahwa subjek memenuhi indikator tahap aksi.

Pada tahap proses, subjek mensketsa grafik dari $f(x)$ yaitu dengan menentukan pasangan titik yang melibatkan proses menentukan nilai suatu fungsi. Selanjutnya, subjek melihat fungsi sebagai suatu input dan output dengan subjek menjelaskan bahwa apabila mensubstitusi sebuah nilai $(x)$ maka akan diperoleh suatu nilai keluaran $(f(x))$. Selain itu, subjek memberikan penjelasan tentang pengertian fungsi. Sehingga, disimpulkan bahwa subjek memenuhi indikator tahap proses.

Pada tahap objek, subjek menjelaskan bahwa semua relasi adalah fungsi dan begitupun sebaliknya, semua fungsi adalah relasi. Hal ini menunjukkan bahwa subjek tidak memberikan penjelasan yang sesuai tentang hubungan antara relasi dan fungsi. Selanjutnya, subjek tidak mudah dalam mengidentifikasi suatu grafik.

\section{TRANSKRIP 2}

\section{P2-01 : "Bagaimana syarat-syarat fungsi dek?" \\ S2-01 : "Menurut saya kak, setiap anggota himpunan A memiliki pasangan di himpunan B dan setiap anggota dari himpunan A memiliki satu pasangan di himpunan B"}

Pada transkrip 2, subjek menyebutkan syarat-syarat fungsi (S2-01). Sehingga, disimpulkan subjek hanya memenuhi satu indikator pada tahap objek. Pada tahap skema, Subjek tidak mengaplikasikan konsep fungsi dalam menyelesaikan soal, hal ini dikarenakan subjek tidak memahami soal dan konsep apa yang dapat ia gunakan dalam pemecahan masalah. Selain itu, subjek tidak mudah dalam menentukan grafik dari persamaan yaitu apabila subjek diberikan suatu fungsi $f(x)$ yang tidak diketahui nilai-nilai $x$ nya. Sehingga, disimpulkan subjek tidak memenuhi satupun indikator pada tahap skema. 


\section{Subjek dengan Kemampuan Matematika Rendah}

Pada tahap aksi, subjek mudah melakukan operasi secara aljabar dalam menentukan nilai suatu fungsi apabila diberikan suatu rumus fungsi yaitu dengan mensubstitusikan nilai $x$ ke dalam $f(x)$. Sehingga, disimpulkan bahwa subjek memenuhi indikator pada tahap aksi.

Pada tahap proses, subjek mensketsa grafik dari $f(x)$ yaitu dengan menentukan pasangan titik yang melibatkan proses menentukan nilai suatu fungsi. Selanjutnya, subjek melihat fungsi sebagai suatu input dan output. Subjek menjelaskan bahwa apabila mensubstitusi sebuah nilai $(x)$ maka akan diperoleh suatu nilai keluaran $(f(x))$.

\section{TRANSKRIP 3}

P3-01

S3-01

: "Bagaimana pengertian fungsi menurut kata-kata kamu sendiri dek?"

" "Menurut saya kak, fungsi adalah suatu aturan yang menghubungkan

setiap anggota himpunan A dengan anggota himpunan B kak"

Pada Transkrip 3, subjek keliru dalam memberikan penjelasan tentang pengertian fungsi. Subjek tidak menyebutkan salah satu syarat fungsi yakni memasangkan tepat satu anggota himpunan A dengan anggota himpunan B (S3-01). Sehingga, disimpulkan subjek tidak memenuhi satu indikator pada tahap proses.

Pada tahap objek, subjek menyebutkan bahwa fungsi dan relasi sama dikarenakan keduanya sama dalam hal menghubungkan himpunan A dan himpunan B. Hal ini menunjukkan bahwa subjek tidak memahami bahwa fungsi adalah relasi yang bersyarat. Subjek juga tidak menyebutkan tentang syarat-syarat fungsi. Hal ini dikarenakan subjek tidak memahami dengan baik pengertian fungsi dan hubungan relasi dan fungsi. Selain itu, subjek tidak mudah dalam mengidentifikasi suatu grafik termasuk fungsi atau bukan. Sehingga, disimpulkan subjek tidak memenuhi satupun indikator tahap objek.

Pada tahap skema, subjek dapat menyebukan diketahui dan ditanyakan dalam soal tetapi tidak dapa menggunakan informasi tersebut dalam menyelesaikan soal. Selain itu, subjek tidak mengetahui konsep yang terlibat dalam menyelesaikan soal. Hal ini menunjukkan bahwa subjek tidak dapat mengaplikasikan konsep fungsi dalam pemecahan masalah. Subjek tidak dapat menentukan grafik dari persamaan yang diberikan. Subjek menjelaskan bahwa dalam menggambar grafik harus diketahui nilai $x$ nya. Hal ini menunjukkan bahwa subjek tidak mudah dalam menentukan grafik dari persamaan. Sehingga, disimpulkan subjek tidak memenuhi satupun indikator pada tahap skema.

\section{KESIMPULAN}

Subjek dengan kemampuan matematika tinggi mencapai tahap skema. Subjek dapat mengaplikasikan konsep fungsi dalam pemecahan masalah. Adapun pada subjek dengan kemampuan matematika sedang mencapai tahap objek dan subjek dengan kemampuan matematika rendah pada tahap proses.

Penelitian ini mengkaji mengenai pemahaman konsep siswa pada materi relasi dan fungsi berdasarkan teori APOS ditinjau dari kemampuan matematika. Peneliti selanjutnya dapat menggunakan penelitian ini sebagai sumber data atau bahan perbandingan dalam melakukan penelitian relevan dengan materi lain, seperti limit fungsi dan turunan fungsi. Selain itu, dapat pula melihat teori-teori tentang pemahaman konsep yang dikembangkan sendiri oleh peneliti lain. 


\section{DAFTAR PUSTAKA}

Asiala, M., Brown, A., Devries, D. J., Dubinsky, E., Mathews, D., \& Thomas, K. (1997). A Framework for Research and Curriculum Development in Undergraduate Mathematics Education. Research in Collegiate Mathematics Education, 2. 1-32.

Chimhande, T., Naidoo, A., \& Stols, G. (2017). An Anlysis of Grade 11 Learners' Levels of Understanding of Function in Terms of APOS Theory. Africa Education Review, 14. 119.

Depdiknas. (2006). Kurikulum Tingkat Satuan Pendidikan (KTSP). Jakarta: Direktorat Jenderal Pendidikan Tinggi Departemen Pendidikan Nasional.

Dubinsky, E., \& McDonald, M. A. (2001). APOS : a Constructivist Theory of Learning in Undergraduate Mathematics Education Research. The Teaching and Learning of Mahematics at University Level : An ICMI study. 275-282.

Febriana, C., \& Budiarto, M. T. (2012). Profil Kemampuan Siswa Sma Dalam Menyelesaikan Soal Fungsi Kuadrat Berdasarkan Teori APOS Ditinjau dari Perbedaan Kemampuan Matematika. Jurnal Matematika, 1(1). 1-7.

Komariyah, S., Afifah, D. S. N., \& Resbiantoro, G. (2018). Analisis Pemahaman Konsep Dalam Memecahkan Masalah Matematika Ditinjau Dari Minat Belajar Siswa. Jurnal LP3M, 4(1). $1-8$.

Maharaj, A. (2010). An APOS Analysis of Students' Understanding of the Concept of a Limit of a Function. Phythagoras, $71: 41-52$.

Mulyono. (2011). Teori APOS dan Implementasinya dalam Pembelajaran. JMEE, 1(1). 37-45.

Rosali, D. F., Asdar, \& Talib. (2019). Deskripsi Kemampuan Pemahaman Konsep Turunan Berdasarkan Teori APOS pada Siswa Kelas XII SMA. Issues in Mathematics Education, 3(1). 49-57.

Safitri, F. L., Susanto, \& Fatahillah, A. (2017). Analisis Pemahaman Matematis Siswa Kelas VIII B SMP Negeri 8 Jember Berdasarkan Polya Dengan Pemberian Scaffolding Pokok Bahasan Kubus Dan Balok. Jurnal Kadikma, 8(2). 155-165.

Sugiyono. (2017). Metode Penelitian Pendidikan: Pendekatan Kuantitatif, Kualitatif, dan $R$ \& $D$. Bandung: Alfabeta.

Syafri, F. S. (2016). Pemahaman Matematika dalam Kajian Teori APOS (Action, Process, Object, and Schema). Jurnal At-Ta'lim, 15(2). 458-476.

Widarti, A. (2013). Kemampuan Koneksi Matematika dalam menyelesaikan Masalah Kontekstual ditinjau dari Kemampuan Matematis Siswa. Jurnal Pendidikan, 1(3). 1-9. 